\title{
A proposal for generic competence assessment in a serious game
}

\author{
María José Bezanilla ${ }^{1, *}$, Sonia Arranz², Alex Rayón ${ }^{3}$, Isabel Rubio ${ }^{4}$, Iratxe \\ Menchaca ${ }^{5}$, Mariluz Guenaga ${ }^{6}$, Eduardo Aguilar ${ }^{7}$ \\ 'Innova Research Team, University of Deusto, Spain \{marijose.bezanilla@deusto.es\} \\ ${ }^{2}$ Innova Research Team, University of Deusto, Spain \{sonia.arranz@deusto.es\} \\ ${ }^{3}$ DeustoTech Learning, University of Deusto, Spain \{alex.rayon@deusto.es\} \\ ${ }^{4}$ Leisure and Human Development, University of Deusto, Spain \{irubio@deusto.es\} \\ ${ }^{5}$ DeustoTech Learning, University of Deusto, Spain \{iratxe.mentxaka@deusto.es\} \\ ${ }^{6}$ DeustoTech Learning, University of Deusto, Spain \{mlguenaga@deusto.es\} \\ ${ }^{7}$ Leisure and Human Development, University of Deusto, Spain \{eaguilar@deusto.es\} \\ Received on 25 March 2013; revised on 29 March 2013; accepted on 16 July 2013; published on 15 January 2014
}

DOI: 10.7821/naer.3.1.42-51

\begin{abstract}
This paper focuses on the design of a serious game for the teaching and assessment of generic competences, placing particular emphasis on the competences assessment aspect. Taking into account important aspects of competence assessment such as context, feedback and transparency, among other aspects, and using the University of Deusto's Generic Competences Assessment Model based on the defining of levels, indicators and descriptors as a reference point, a serious game has been designed for the development and evaluation of two Generic Competences: Problem Solving and Entrepreneurship, aimed at final-year undergraduate and first-year postgraduate students. The design process shows that having a Competence Assessment Model based on levels, indicators and descriptors is of great help in defining the game's scenarios and learning and assessment activities. Serious games can also be excellent resources to help in the development and assessment of generic competences, but not as a unique tool, since the concept of competence in itself is highly complex (integrating knowledge, skills, attitudes and values) and some elements might require other methods and techniques for its development. It also reveals the difficulties of evaluating competences in general and through serious games in particular.
\end{abstract}

KEYWORDS: EVALUATION, ASSESSMENT, SKILLS, COMPETENCES, VIDEO GAMES

\section{INTRODUCTION}

This paper discusses the design of a serious game for the development of generic competences in terms of evaluation, i.e., it focuses on how to evaluate generic competences via a serious game. Starting from a theoretical analysis of competence

\footnotetext{
${ }^{*}$ To whom correspondence should be addressed:

Universidad de Deusto

Avda. De las Universidades, 24

48007 Bilbao

Spain
}

assessment in general, it moves on to the design of the evaluation strategy of two Generic Competences (Problem Solving and Entrepreneurship) in a serious game being developed by the University of Deusto, and is aimed at finalyear undergraduate and first-year postgraduate students. The University of Deusto's Competence Assessment Model, based on a structure of levels, indicators and descriptors, has been followed in order to design the evaluation strategy in the serious game. The study is part of a project which is in process of development, being at the present moment at the pilot experimentation phase.

\section{COMPETENCE-BASED LEARNING AND ASSESSMENT}

\subsection{Competence-Based Learning}

Competence-based learning is an approach to learning and teaching that focuses on the development of generic or transversal competences (common to different study programs) and specific competences (belonging to each individual study program) that allow a person to gain scientific knowledge and techniques for their career, apply them in diverse and complex contexts, and incorporate them into their own attitudes and values in their own personal and professional way of acting (Villa \& Poblete, 2008). This approach has progressively been introduced into European universities since the Bologna Declaration (1999) and is giving rise to significant methodological and organizational changes within universities. Competence-based learning entails passing from the teaching paradigm to the learning paradigm, from an education system based on the transmission of knowledge to an education system that places students' learning at the educational center of its action (Legault, 2012; Villa, Gonzalez, Auzmendi, Bezanilla \& Laka, 2003).

There are several definitions of Competence. Villa \& Poblete (2008) see competence as "good performance in diverse, authentic contexts based on the integration and activation of knowledge, rules and standards, techniques, procedures, abilities 
and skills attitudes and values" (p. 29). The Tuning Project (2008, p. 139) concludes that "competences represent a dynamic combination of cognitive and metacognitive skills, knowledge and understanding, interpersonal, intellectual and practical skills, and ethical values". After reviewing various definitions of the term "competence", Rodríguez \& Vieira (2009) concluded that competences:

- Are based on action in order to respond successfully to a demand or purpose

- Are linked to a context

- Are verifiable, and they can be learned and evaluated

-Mobilize and integrate different elements: knowledge, skills, procedures and attitudes.

There is often no distinction made between competence and skill in existing literature, and sometimes different terms are used to refer to the same concept. "Transferable skills", "general skills", "key skills", "common skills" are defined differently by different authors but, on the whole, they all refer to the skills needed for employment and for life as a responsible citizen, which are important for all students regardless of the discipline they are studying (Fallows \& Steven, 2000). As can be seen, competence refers to integrated behavior in which skills are an important component, as well as others such as knowledge, attitudes, rules and values. In this respect, Haste (2009, p. 207) states that "'competence' does not mean skills (although it may include skills)."

Emphasis must therefore be placed on the integrative character of the concept of competence, in which different resources combine in order to respond to a given situation, as can be seen in Figure 1.

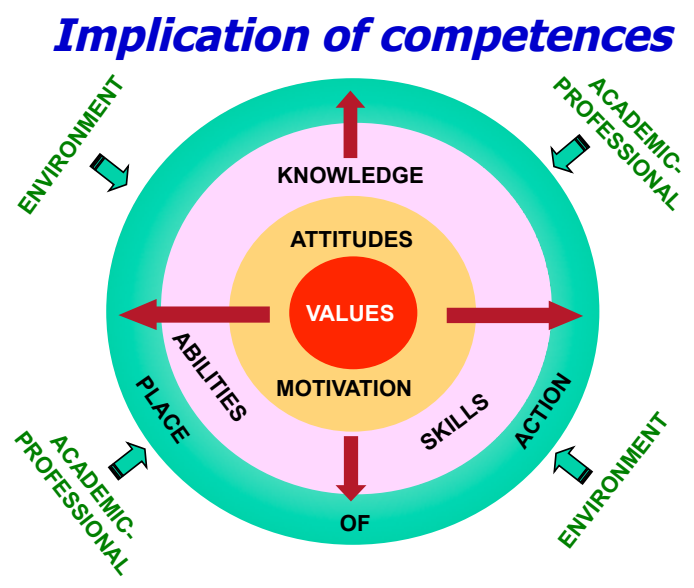

Figure 1. The concept of competence at the University of Deusto (Poblete 2003, cited in Poblete \& García, 2007, p. 51)

\subsection{Competence assessment}

Assessment is normally one of the major sources of dissatisfaction among university students (Ferrell, 2012). Nonetheless, its importance in learning processes is vital. In the 1970 s a great deal of research already showed that what most influenced learning was not teaching but assessment (Boud \& Falchikov, 2007). It is undeniable that assessment is currently of major importance to the university student and a key element that orients their learning, since students focus their attention and organize their way of studying by tailoring it to the type of assessment. (Villa \& Poblete, 2011). Evaluation should therefore be carefully designed so that it becomes a precise tool that contributes to the attainment of deep learning.

The transition from a traditional learning and teaching model to a competence-based model involves changes in the way of conceiving evaluation because traditional evaluation methods are no longer of use in assessing complex competences (Griffin, McGaw, \& Care, 2012).

In this new model, defining the competences we want the students to acquire is not enough - both the assessment and teaching methods must also be defined on the basis of the competences that wish to be attained. Succeeding in making assessment a strategy that encourages the development of students' competences remains one of the greatest challenges facing university teaching.

It is therefore necessary to rethink aspects such as what to evaluate, when, who, what for or how (Figure 2).

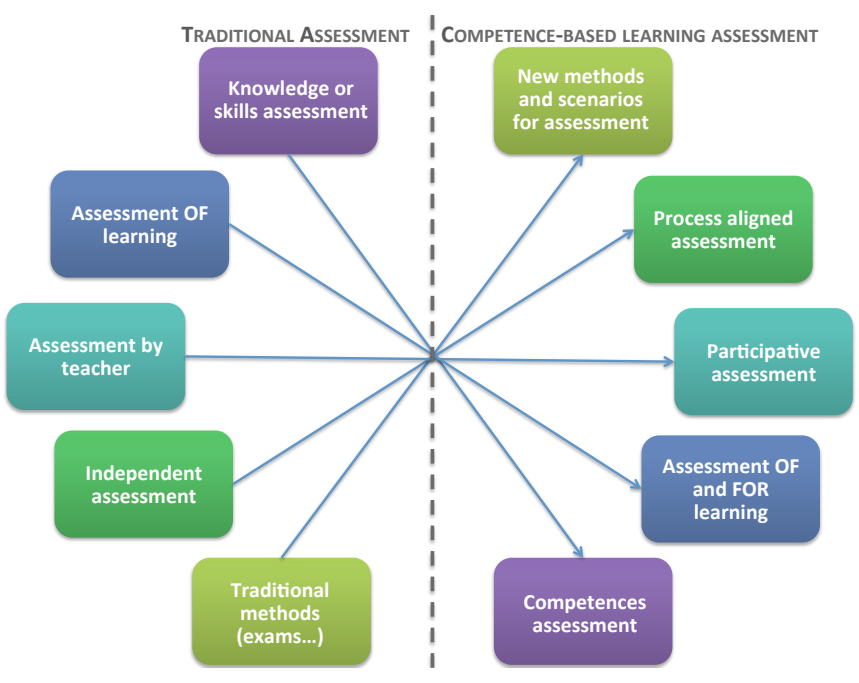

Figure 2. Transition of the assessment model

Aspects such as formative assessment, student participation in assessment processes, the use of methods that go beyond the traditional exam, etc., are by no means novel concepts. Nevertheless, their implementation in universities is proving complicated and their degree of integration is still rather limited.

\subsection{A model for generic competence assessment in higher education}

The University of Deusto has developed a generic competence assessment model that has been used as a reference point for designing competence assessment in the serious game now being developed.

The generic competence assessment model includes three elements:

Firstly, what one wishes to assess. The University of Deusto has defined 35 generic competences in this respect, grouped into three categories: instrumental competences, interpersonal competences and systemic competences (Universidad de Deusto, 2001). This proposal of competences along with other initiatives by European universities was the seed that sprouted the study of generic competences undertaken by the Tuning Project (Gonzalez \& Wagenaar, 2003), which was first led by the Universities of Deusto and Gröningen and has spread further 
afield to other European universities, where more than 200 universities are involved, as well as other countries in Latin America and Asia.

The University of Deusto's competence assessment model (Figure 3) provides the following information about each of the competences (Villa \& Poblete, 2008, p. 51-52):

-A definition that specifies and pinpoints the meaning that one wishes to be expressed under the term describing each competence. Such a definition solely intends to pinpoint the meaning given to it in this model, which may be different to how it is interpreted in other models or approaches.

- The linking of competence with other closely-related competences, attitudes and values. Competence, as a human activity, is complex and is made up of skills, values and knowledge that cannot be separated from one another, nor can any claim full credit. Moreover, when one works in the learning of certain competences, it is wise to be aware of the fact that others are also developing.

- The distinction of each competence in three levels of mastery. The first level reflects the competence's mastery within the person's normal context - a context where the person has to carry out their normal activities in familiar, everyday conditions. The second level indicates a mastery of the competence that displays good use of technique or competent, personal ways of acting. The third level refers to using the competence in different, complex situations. On the whole, it refers to situations of a professional nature, albeit not necessarily.

-A number of indicators constituting clues or evidence of the competence's degree of development.

- Each of the indicators is then fixed on a scale of five descriptors, which are easily translatable into traditional grades.

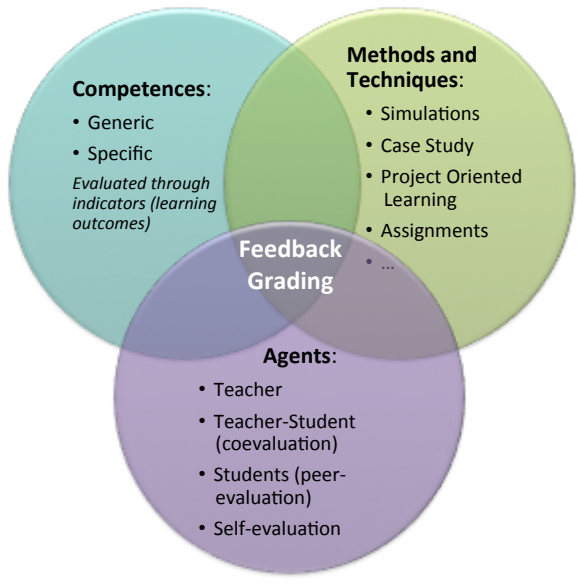

Figure 3. Generic Competence Assessment, University of Deusto (adapted from Villa \& Poblete, 2008)

An example of generic competence in accordance with this model is shown below (Table 1)

Secondly, the competences assessment model requires explicit definitions to be given as to how generic competences will be assessed, i.e., what techniques and instruments will be used for the assessment and when they will be applied (at the beginning, during or at the end of a learning process) and who is going to take part in the assessment: only the teacher, the teacher with the student (shared assessment), the student by means of selfassessment and/or the students among themselves (peer assessment).

Thirdly, a rating or weighting system for the final grade must be established, i.e., the weight each competence will have in the final rating. The model also allows different weights to be given to each competence's assessment indicators.

The following figure (Figure 4) shows the University of Deusto's competence assessment system.

\section{DEFINITION}

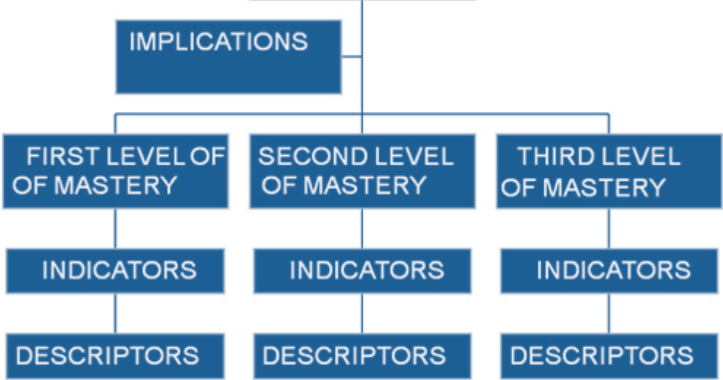

Figure 4. Assessment elements, University of Deusto

\section{WHAT ARE SERIOUS GAMES AND WHAT DO THEY CONTRIBUTE TO LEARNING AND ASSESSING COMPETENCES?}

\subsection{What are serious games?}

The game's overall function -and that of the video game in particular- as a tool for behavior and attitude learning, has been used in education for some years. When categorizing games, it is useful to consider the primary function of the game. Games are commonly played for fun and entertainment; however, some argue that they are played primarily to learn, even if it is with unconscious intent (Crawford, 1982). Serious games are a type of video game, characterized by being designed specifically for education, training and information purposes (Michael \& Chen, 2006). This does not mean they cannot be fun as well, but the game's amusement is designed for learning purposes so that student learning becomes enjoyable (Koster, 2004).

The terms serious games and Game-based learning are sometimes used synonymously, although serious games have been developed for the broader purposes of training, and behavior and attitudes have changed in business, industry, marketing, healthcare, government and NGOs, as well as in education. On the other hand, commercial digital games are mainly developed for fun and entertainment, and so the distinctive features of serious games in relation to video games with a purely commercial aim could be summarized as follows (Marcano, 2008):

- Serious games are oriented to education, skills training or the understanding of certain complex processes (social, political, economic, etc.)

— They model real-life situations 
Table 1. Example of Generic Competence: Problem Solving. Level 2

\begin{tabular}{|c|c|c|c|c|c|}
\hline COMPETENCE & \multicolumn{5}{|l|}{ Problem solving } \\
\hline $\begin{array}{l}\text { SECOND LEVEL OF } \\
\text { MASTERY: }\end{array}$ & \multicolumn{5}{|c|}{$\begin{array}{l}\text { Using own experience and criteria to analyze the causes of a problem and construct a more efficient, effective } \\
\text { solution }\end{array}$} \\
\hline INDICATORS & 1 & 2 & 3 & 4 & 5 \\
\hline $\begin{array}{l}\text { Recognizing a complex } \\
\text { problem and being able to } \\
\text { break it down into } \\
\text { manageable parts }\end{array}$ & $\begin{array}{l}\text { Is unable to } \\
\text { handle complex } \\
\text { problems. }\end{array}$ & $\begin{array}{l}\text { Has difficulty in seeing } \\
\text { and analyzing the } \\
\text { complexity of a problem, } \\
\text { doesn't manage to break it } \\
\text { down into manageable } \\
\text { parts. }\end{array}$ & $\begin{array}{l}\text { Identifies complex } \\
\text { problems, analyses } \\
\text { them and } \\
\text { subdivides them } \\
\text { into manageable } \\
\text { parts. }\end{array}$ & $\begin{array}{l}\text { Makes a good } \\
\text { analysis that } \\
\text { includes priorities } \\
\text { and breaks down the } \\
\text { problem into } \\
\text { manageable parts. }\end{array}$ & $\begin{array}{l}\text { Has comprehensive view, } \\
\text { brilliantly recognizes the } \\
\text { parts of the problem and } \\
\text { how they are related. }\end{array}$ \\
\hline $\begin{array}{l}\text { Contrasting sources of } \\
\text { information and handling } \\
\text { facts rigorously }\end{array}$ & $\begin{array}{l}\text { Doesn't worry } \\
\text { about the } \\
\text { rigorousness of } \\
\text { information. }\end{array}$ & $\begin{array}{l}\text { Needs help in checking } \\
\text { reliability of sources of } \\
\text { information and strength } \\
\text { of facts. }\end{array}$ & $\begin{array}{l}\text { The facts he/she } \\
\text { uses are rigorous } \\
\text { and come from } \\
\text { trustworthy } \\
\text { sources. }\end{array}$ & $\begin{array}{l}\text { Handles hard facts } \\
\text { and knows how to } \\
\text { manage conflicting } \\
\text { information from } \\
\text { different sources. }\end{array}$ & $\begin{array}{l}\text { Provides noteworthy } \\
\text { analysis of conflicting } \\
\text { information drawn from } \\
\text { different sources, and } \\
\text { even contributes new } \\
\text { sources. }\end{array}$ \\
\hline $\begin{array}{l}\text { Having a method of } \\
\text { analysis for identifying } \\
\text { elusive underlying causes } \\
\text { and evaluating their } \\
\text { impact on problems }\end{array}$ & $\begin{array}{l}\text { Makes deficient } \\
\text { analyses of } \\
\text { causes. }\end{array}$ & $\begin{array}{l}\text { Identifies causes, but still } \\
\text { doesn't evaluate their } \\
\text { impact on problems. }\end{array}$ & $\begin{array}{l}\text { Correctly follows a } \\
\text { method to identify } \\
\text { causes and } \\
\text { evaluate their } \\
\text { impact. }\end{array}$ & $\begin{array}{l}\text { Provides a good } \\
\text { method of analysis } \\
\text { for identifying } \\
\text { causes. }\end{array}$ & $\begin{array}{l}\text { In addition to providing a } \\
\text { good method of analysis } \\
\text { for identifying causes, } \\
\text { evaluates their impact } \\
\text { with comprehensive } \\
\text { view. }\end{array}$ \\
\hline $\begin{array}{l}\text { Presenting solution options } \\
\text { that are most often } \\
\text { effective for resolving } \\
\text { problems. }\end{array}$ & $\begin{array}{l}\text { Doesn't present } \\
\text { any solutions. }\end{array}$ & $\begin{array}{l}\text { Presents solutions, but } \\
\text { they are not effective. }\end{array}$ & $\begin{array}{l}\text { Presents more than } \\
\text { one effective } \\
\text { alternative } \\
\text { solution. } \\
\end{array}$ & $\begin{array}{l}\text { Presents array of } \\
\text { options with } \\
\text { effective solutions. }\end{array}$ & $\begin{array}{l}\text { The options proposed } \\
\text { feature diversity, rigor } \\
\text { and internal logic. }\end{array}$ \\
\hline $\begin{array}{l}\text { Having good criteria for } \\
\text { choosing between } \\
\text { alternative solutions }\end{array}$ & $\begin{array}{l}\text { Lacks criteria. } \\
\text { Doesn't know } \\
\text { how to justify } \\
\text { his/her decision. }\end{array}$ & $\begin{array}{l}\text { Utilizes criteria } \\
\text { inappropriately. }\end{array}$ & $\begin{array}{l}\text { Correctly utilizes } \\
\text { the criteria offered } \\
\text { for choosing a } \\
\text { solution. }\end{array}$ & $\begin{array}{l}\text { Applies the most } \\
\text { appropriate criteria } \\
\text { for weighing } \\
\text { options and } \\
\text { choosing the right } \\
\text { solution. }\end{array}$ & $\begin{array}{l}\text { Develops own criteria } \\
\text { that lead to selecting the } \\
\text { best of alternative } \\
\text { solutions. }\end{array}$ \\
\hline $\begin{array}{l}\text { Devising a realistic plan of } \\
\text { action and follow-up for } \\
\text { applying the solution }\end{array}$ & $\begin{array}{l}\text { Doesn't devise a } \\
\text { realistic plan of } \\
\text { action. }\end{array}$ & $\begin{array}{l}\text { His/her plan of action is } \\
\text { realistic but lacks a } \\
\text { follow-up plan. }\end{array}$ & $\begin{array}{l}\text { His/her plan of } \\
\text { action is realistic } \\
\text { and includes a } \\
\text { follow-up plan. }\end{array}$ & $\begin{array}{l}\text { His/her plan of } \\
\text { action and follow- } \\
\text { up plan noteworthy } \\
\text { for their quality. }\end{array}$ & $\begin{array}{l}\text { Noteworthy for the } \\
\text { quality of his/her plan of } \\
\text { action and follow-up } \\
\text { plan. Foresees } \\
\text { contingency plans. }\end{array}$ \\
\hline
\end{tabular}

- The interests are declared in the content (political, economic, psychological, religious, etc.)

Bearing in mind the definition given to the term serious game by Abt (1970), we have considered the following structural components for the formal modeling of our game design:

-Objectives: must be clearly defined and known at all times by the player. In the context of an educational serious game, they will be explicit in the competences to be exercised.

- Rules: this component will determine the order, rights and responsibilities of the players, as well as the objectives to be achieved by each player in order to reach the challenge they face.

-Challenge: this determines when the game is completed. The player will face problems for which solutions will be sought. Once they all are solved, the challenge will be met. For the proposed serious game, partial and overall game closure criteria will be specified in learning outcomes.

-Interaction: this is the component arising from the game mechanics and dynamics and will lead to all the experiences the player will enjoy. These will emerge continuously as the result of the immediate feedback the game provides and also show evidence of progress toward the final challenge (end game criteria).

These serious games can be used to meet training objectives in knowledge areas as varied as defense, education, scientific exploration, health, public policy, strategic communications, emergency management, etc.

\subsection{What is serious games contribution to the learn- ing and evaluation of competences?}

Numerous studies exist in the area of video games and serious games that deal with their relationship with learning (Connolly, Boyle, MacArthur, Hainey and Boyle, 2012; Guillen-Nieto \& Aleson-Carbonell, 2012). The latest advances in cognitive sciences broadly support the learning principles the games incorporate (Gee, 2003) and highlight the need for the experiential and active nature of learning for a protagonist who rises to the challenge of solving specific problems, and the context subsequently sends them real-time feedback on the process. From the standpoint of learning theories, Connolly et al. (2012) state that serious games are built under the principles of constructivism, situated learning, learning based on problem solving and cognitive learning. When analyzing game-based learning, Wu, Hsiao, Wu, Lin \& Huang (2012) added that 
another of the most widely used principles in this type of game is the experiential principle.

Modern theories of effective learning suggest that learning is most effective when it is active, experiential, situated, problembased and provides immediate feedback (Boyle, Connolly \& Hainey, 2011). In Games-Based Learning (GBL), students develop communication or behavior strategies to reach a goal by handling situations, taking into account elements of contrast and trying different approaches to see how the environment reacts to their actions.

Suggestions that game players might actually be developing useful skills led to optimism that games might provide a useful and attractive new method of learning (de Freitas, 2006) and have a huge educational potential (Gee, 2003; Salen \& Zimmerman, 2004; Squire \& Jenkins, 2003). So much so that Prensky (2001) argues that video games could be the mechanism with the greatest learning potential ever known. Prensky postulates that while it is possible to adjust the content of video games so that they are more in line with the objectives of learning and socialization, the actual content of the game itself, with its rules and organization -beyond the content- enables a great deal of positive learning.

Regarding the specific learning developed by video games, in addition to certain tasks and/or training, aspects can be seen in literature confirming that not only is content acquired and concepts understood with these kinds of games, but that they also promote the acquisition of certain skills and competences (Gee, 2009). The motivational components, the knowledge generated, accessibility, strategies, skills, active experimentation and learning based on the solving of specific problems that serious games can develop can make them an element with huge potential in the development of competences.

Indeed, authors such as Gros (2008) believe that they encourage self-esteem and have a motivational factor, in addition to the chance to develop cognitive skills and strategies, such as problem-solving skills, decision-making, searching and organizing information, perceptual motor skills and abstract reasoning. Moreover, it can be added that they increase coordination capacity, spatial perception and broaden our field of vision (Prensky, 2001), which has an impact on reading and efficient handling in 3D environments. They also encourage socialization since they act as instruments for the transmission of behavioral patterns, values and favorable attitudes in certain contexts and they improve cognitive processes such as reasoning, memory and social interaction skills, especially with games of a strategic nature.

Research shows that the clearest impact of video games' formative potential is shown by the acquisition of digital competences (Prensky, 2005). Other authors are more specific and state that the following are developed: communicative skill (Gros \& Grup F9, 2004; Lacasa, Méndez and Martínez, 2008), resource management and reflective criticism (Sedeño, 2010), and negotiation and decision taking (Gros \& Grup F9, 2004), the deployment of organizational, design and planning strategies is also pointed out (Gros, 2008), in addition to strategic reasoning (Sedeño, 2010).

Prensky (2005) maintains that it is possible to learn many skills thanks to serious games: collaboration, decision decisionmaking under pressure, calculated risk taking, lateral thinking and ethical behavior. He also states that many current games "require the learning of difficult, complex skills to achieve goals that are quite a challenge, which will be of great use to players for life in the 21st century" (Prensky, 2005, p. 37). O'Neill,
Wainess and Baker (2005) identify five types of demand of a cognitive nature in video games: content understanding, problem solving, self-regulation, communication and collaboration or teamwork.

According to these criteria, the use of video games and serious games in particular in the development of competences has been made clear. In this sense, it is especially important to follow the principles put forward by Gee (2003), in particular; to offer information on demand and just at the right time, offer the possibility to customize the experience, make it easy for players to become content creators and not simply consumers, encourage progressive adaptation to the game's needs, implement a cycle of experience that repeats itself throughout the game, supervise, respect and maximize motivating elements and allow experimentation in the game under new identities or roles.

\section{A PROPOSAL FOR THE DESIGN OF A SERIOUS GAME TO DEVELOP TWO GENERIC COMPETENCES: PROBLEM SOLVING AND ENTREPRENEURSHIP}

\subsection{Why we decided to use a serious game to devel- op competences?}

The proposed serious game has been designed with the aim of helping the student develop Entrepreneurship and ProblemSolving generic competences, since they are essential for the continuing education the student will need to pursue throughout their life.

Games play an important role in students' everyday lives, as can be seen by the interest they show in them in their leisure time. Thus, video games become an excellent tool as they provide different aspects of a game, such as entertainment, a psychological boost and competition and collaboration (Wolf, 2003). Within this context, our proposal is to use a serious game to join real and virtual environments within the classroom, allowing students to actively reflect on the relationship between the game content and contexts of everyday activity (Gee, 2008). Figure 5 shows the main characters of the game within the Maze which gives entrance to University.

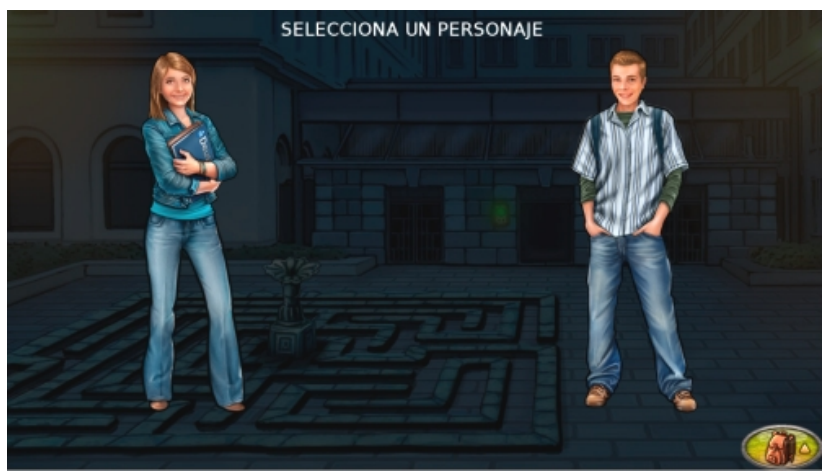

Figure 5. Main characters

Bearing this latest goal in mind, one of the most interesting concepts that help us understand the role of video games as cultural and educational instruments is situated cognition (Holland \& Lave, 2001). From this point of view, cognition is narrowly linked to environment, action and experience. Furthermore, knowledge is acquired not only through the ability to perform an action, but also the opportunities offered by the 
environment that make sense in specific contexts. These specific scenarios, combined with related rules defining the precise game dynamics, constitute the standpoint from which to analyze student activity. Moreover, games provide the ability to interpret and construct dynamic models of processes taking place in the real world. Thus, this game is presented as a representation of everyday experiences at the University of Deusto for our students, since the game adventure takes place at the university (albeit at night) and the graphic environment recreates particularly symbolic scenarios of it (see Figure 6). Gee (2003) assumes that a cultural universe involves images, history, principles or metaphors that capture what a particular group of students consider normal about a certain phenomenon, and so our University's context becomes suitable for the purpose of attaining our learning objectives. Video games provide the power to force their players to engage in different practices with a particular goal that could prove attractive to them, since they do so with a sense of purpose that they either generate or accept.

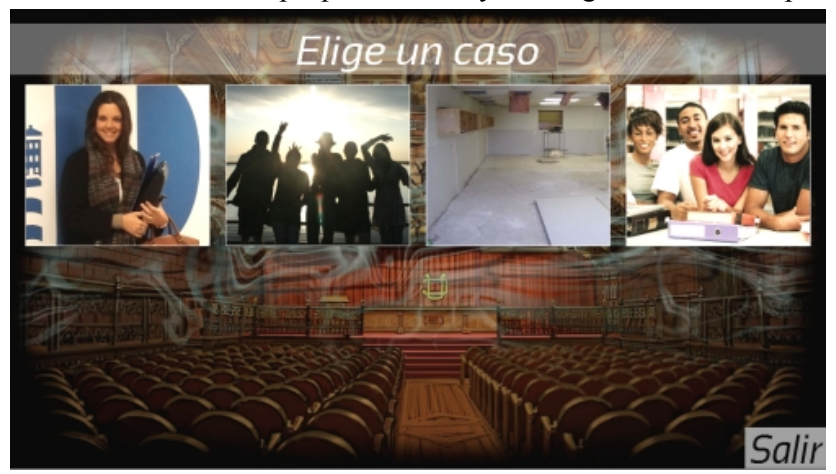

Figure 6. Assembly Hall

All games are composed of a set of rules restricting their action, forcing players to manage available resources. Thus, the rules of a game force the player to think and compare the game with what they already know about the fact that the game simulates. This is an important lesson for real life (Prensky, 2002). These rules and pursued fun might seem to be two opposing terms, but the rules in video games are the most consistent source of amusement for the player (Juul, 2005) since they could be seen as the prohibition of something that students wish to do as players. Their combination in the form of specific configurations makes the strategies required to succeed in a game even more complex than the rules themselves. Thus, we can consider that the games force players to form their own simulated results from their own experience of the game (Del Castillo, Herrero, Monjelat, García, \& Checa, 2011) by developing the proposed competences in the serious game being described.

The simulation that every serious game involves emphasizes learning processes that focus on how we learn rather than what we learn. Understanding learning through reflection and management, such as these serious games allow, better prepare the student to put them into action. The development of inductive and deductive thinking for the problem-solving competence can be worked on, generating new ideas and further testing. It is a way to prepare students to better handle change and unfamiliar situations.

\subsection{Project development process}

The serious game design for training in competences has been developed within the framework of the Bizkai Lab scheme, a scheme set up by the Provincial Council of Bizkaia that backs University of Deusto research projects. DeustoTech Learning, DeustoTech Computing, Institute of Leisure Studies and Innova research groups have joined forces to develop the project. Hence, an effective multidisciplinary group has been created to address the different dimensions of the project: the pedagogical and didactical framework, area of innovation and the technology and leisure perspective. The terms and conditions of the BizkaiLab scheme that enables the project to be developed stipulated a total of 3,300 hours for the entire team and a 12month time frame. In this respect, the team had to adapt to the scheme's terms and conditions in order to ensure the project's viability and thus take decisions regarding design and development.

This project aims to develop a serious game in order to exercise and assess generic competences. In this sense, in the initial phases of the project the team decided that the game would address the development of competences at levels corresponding to the final undergraduate and initial postgraduate academic years.

These competences were not chosen arbitrarily; rather, the criteria summarized below were followed. Firstly, the team focused on the competences most regularly developed on the different degree courses in the final undergraduate and initial postgraduate academic years. Secondly, the "playability" of the competences was analyzed, i.e., the types of activities performed in the analyzed serious games were taken into account while the state of the art was being reviewed and, taking resources into consideration, some competences such as oral and written communication were ruled out. Finally, another selection criterion taken into consideration was the relationship of competences with the goal of employability, given that one of the aims within the terms and conditions of the BizkaiLab scheme was to develop projects designed to promote employability. In this respect, it was concluded that the two competences that best fulfilled such requirements were entrepreneurship and problem solving.

Determining the target group also led to the analysis of the characteristics, taste and interests of students when it came to choosing their leisure experiences (see Figure 7). The task of defining the target group was essential because the scheme sought to respond to their needs and interests so that the intrinsic motivational factor in serious games could be tackled.

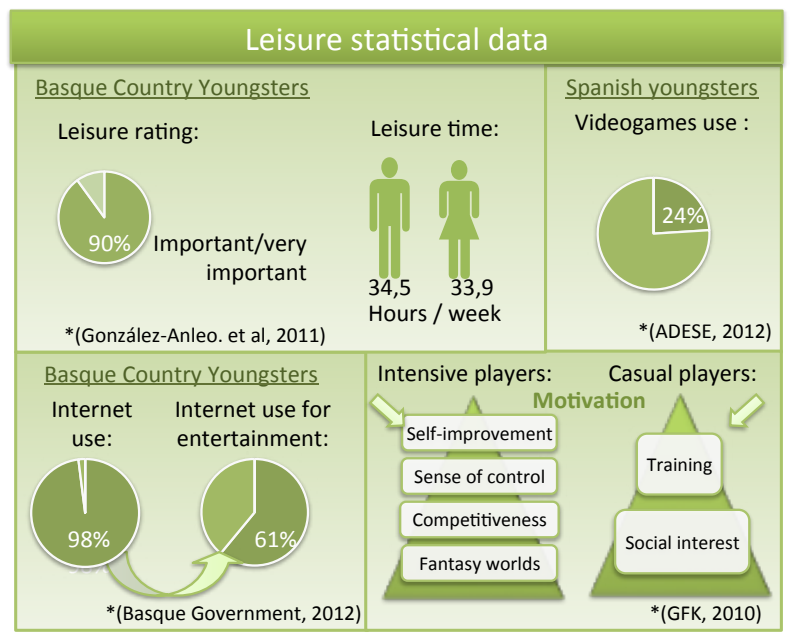

Figure 7. Features of the game's target group 
Table 2. Relationship between evaluated games, competences and indicators

\begin{tabular}{|c|c|c|c|c|}
\hline Scenario & Mini game & Competence & Level of mastery & Indicators \\
\hline \multirow{3}{*}{$\begin{array}{l}\text { 1. Maze } \\
\text { Description: entrance to the University via } \\
\text { the maze. Next to the door (closed), there } \\
\text { is a visible alarm, with a light or similar to } \\
\text { indicate their state }\end{array}$} & $\begin{array}{l}\text { 1- Minotaur } \\
\text { Game }\end{array}$ & $\begin{array}{l}\text { Problem- } \\
\text { solving }\end{array}$ & $\begin{array}{l}\text { 1. Identifying and analyzing a } \\
\text { problem to generate alternative } \\
\text { solutions by applying methods } \\
\text { learned }\end{array}$ & $\begin{array}{l}\text { 1.2. Reading and/or listening } \\
\text { actively. Asking questions to } \\
\text { define the problem at hand }\end{array}$ \\
\hline & \multirow{2}{*}{$\begin{array}{l}\text { 2- Water and } \\
\text { water pipes } \\
\text { Game }\end{array}$} & \multirow{2}{*}{$\begin{array}{l}\text { Problem- } \\
\text { solving }\end{array}$} & $\begin{array}{l}\text { 1. Identifying and analyzing a } \\
\text { problem to generate alternative } \\
\text { solutions by applying methods } \\
\text { learned }\end{array}$ & $\begin{array}{l}\text { 1.1. Identifying what is and is } \\
\text { not a problem, taking the } \\
\text { decision to address it }\end{array}$ \\
\hline & & & $\begin{array}{l}\text { 2. Using own experience and } \\
\text { criteria to analyze the causes of a } \\
\text { problem and construct a more } \\
\text { efficient, effective solution. }\end{array}$ & $\begin{array}{l}\text { 2.1. Recognizing a complex } \\
\text { problem and being able to } \\
\text { break it down into } \\
\text { manageable parts }\end{array}$ \\
\hline
\end{tabular}

The fact that the project targeted university students in their final undergraduate and initial postgraduate academic years also enables the project's future experimentation and substantiation in a real scenario. It will therefore be crucial to establish, during the project's implementation phase, a complete assessment system providing information on the serious game's degree of usability, its formative capacity in competences, the students' degree of satisfaction and participant teachers' assessment. All of the assessments will be used to improve and adapt the serious game to the new needs detected.

The project is divided into three phases and the team is currently in the project's third phase - the pilot development phase. A description of the objective and milestones reached in each of the phases is given in Figure 8.

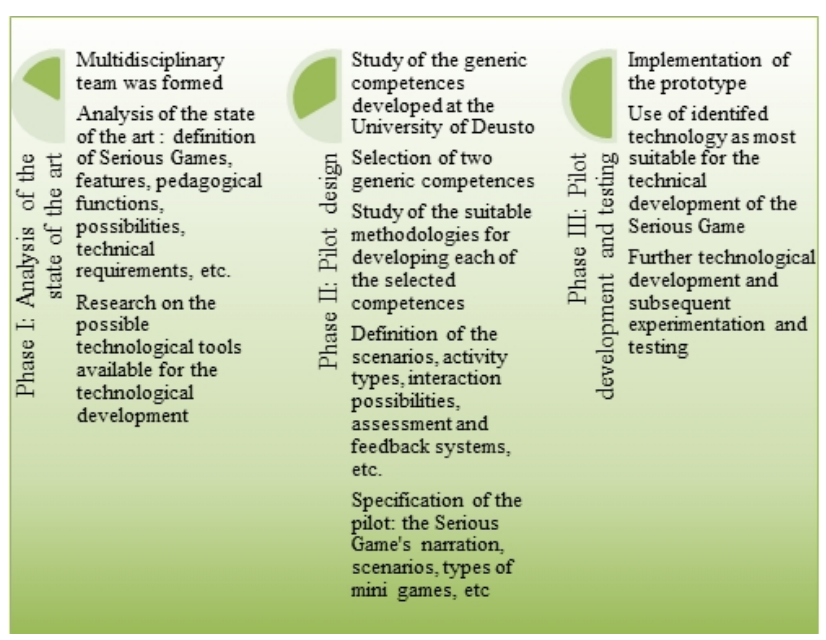

Figure 8. Project phases

\subsection{Features of the serious game's assessment sys- tem}

As mentioned above, a competence-based training model requires a rethinking of the assessment system in order to move from a traditional evaluative model to a model designed for the development of competences. In the design presented, we have attempted to include the competence assessment principles outlined above. Listed below are the principles we have highlighted as being important, together with the way in which they have been implemented in the game.
Coherence between training and assessment: In a competencebased learning model, it is essential that coherence exists between the competences to be attained, the methods defined to achieve them and the assessment systems implemented. It is what Biggs \& Tang (2011) calls aligned teaching. The game design set out from the competences and these have been the permanent reference point for the design of the formative activities and assessment system. In effect, as can be seen in Table 2, all the game's activities have a clearly established level of competence and working indicators.

Assessing globality: A competence is made up of different elements (knowledge, skills, attitudes, motivation, values, etc.) and its assessment cannot be the result of adding up partial results for the different components in order to obtain a final rating (de la Orden, 2011; Villa \& Poblete, 2011). It was decided that global activities would be incorporated into the game that allow several indicators from one competence to work, using cases, projects, etc., which gave a more holistic view of the level of achievement.

Taking the context into account and transferring the knowledge to new situations: Competence assessment should be performed in the most familiar situation possible to the context in which the students develop (Fernández, 2010; Villa \& Poblete, 2011). Solving cases, problem-based learning, projectoriented learning and, of course, simulations and games can all be of use for such purpose as they help the student get their bearings in different scenarios and show their degree of competence. The students are given the chance to experiment with different topics, scenarios and cases in the game, and can sometimes even choose the topic to be addressed -we felt that this was important because the game is aimed at all the university students regardless of their different academic areas and the game had to adapt itself to different student profiles.

Diversifying assessment methods and techniques: Given the importance of assessment in the way students organize their studies, the methods and instruments used for assessment will determine whether the students develop superficial or deep learning (Villa \& Poblete, 2011). In the game, we have done our utmost to ensure that the assessment methods are as heterogeneous as possible, ranging from activities based on a system of questions and answers to the solving of cases or designing of projects. 
Table 3. Example of a competence's score distribution

\begin{tabular}{|c|c|c|c|c|}
\hline Indicator $/ \mathrm{LO}$ & $\begin{array}{c}\text { Indicator } \\
\text { weight }\end{array}$ & Mini game & Who assesses & Weight \\
\hline \multirow{3}{*}{ 1.1. Taking initiative in daily situations } & \multirow{3}{*}{$20 \%$} & Evacuation of the assembly hall & System & 10 \\
\hline & & \multirow{2}{*}{$\begin{array}{l}\text { Entrepreneurial project - } \\
\text { brainstorming }\end{array}$} & System & 5 \\
\hline & & & Peers & 5 \\
\hline \multirow{3}{*}{$\begin{array}{l}\text { 1.2 Weighing up risks and opportunities, taking decisions as } \\
\text { accordingly }\end{array}$} & \multirow{3}{*}{$15 \%$} & \multirow{3}{*}{$\begin{array}{l}\text { Evacuation of the assembly hall } \\
\text { Entrepreneurial project - the circle } \\
\text { closes in }\end{array}$} & System & 5 \\
\hline & & & Self-assessment & 5 \\
\hline & & & Peer assessment & 5 \\
\hline \multirow{3}{*}{ 1.3. Being able to anticipate the effects of actions undertaken } & \multirow{3}{*}{$10 \%$} & Evacuation of the assembly hall & System & 4 \\
\hline & & \multirow{2}{*}{$\begin{array}{l}\text { Entrepreneurial project - the circle } \\
\text { closes in }\end{array}$} & Self-assessment & 3 \\
\hline & & & Peer assessment & 3 \\
\hline \multirow{3}{*}{ 1.4 Including social criteria in one's own decision-making } & \multirow{3}{*}{$10 \%$} & Evacuation of the assembly hall & System & 2 \\
\hline & & \multirow{2}{*}{$\begin{array}{l}\text { Entrepreneurial project - the circle } \\
\text { closes in }\end{array}$} & Self-assessment & 4 \\
\hline & & & Peer assessment & 4 \\
\hline \multirow{4}{*}{ 1.5 Having enough self-esteem to take initiatives } & \multirow{4}{*}{$10 \%$} & Shower of mortarboards & System & 2 \\
\hline & & \multirow{3}{*}{$\begin{array}{l}\text { Entrepreneurial project - } \\
\text { communicating }\end{array}$} & Lecturer & 2 \\
\hline & & & Self-assessment & 3 \\
\hline & & & Peer assessment & 3 \\
\hline
\end{tabular}

Providing students with information on their progress: Feedback is an essential element of competence-based learning, whose purpose is to give the student continuous updates on their achievements and difficulties (de Miguel, 2006). This is perhaps one of the aspects that has received the most attention throughout the serious game's design process, seeking to provide the player with immediate, detailed, relevant and motivating feedback at all times. An example of feedback within the mini game "Evacuation of the Assembly Hall" in which students need to take decisions for solving everyday life problems (in this case related to team work) is the following: "Have you thought of how this decision will affect the clima of the team? and to its quality? ¿and to the grades that each of you will get? It seems that this decision affects the team projects of several subjects. Are you sure you can take charge of his/her work in every case? Is this fair? What will happen in following projects?".

The intervention of different agents in the assessment process: An increasing number of authors agree that both selfassessment and peer-assessment, in addition to contributing to learning, help students learn evaluative skills, which they will need to develop both in their academic lives and careers (Biggs \& Tang, 2011; Boud \& Falchikov, 2006). These ways of actively participating in the evaluative process will enable them to be more self-critical of their degree of competence achievement, develop their autonomous learning competence and improve their determination thanks to their colleagues' feedback and also the effort involved in evaluating their peers and providing accurate feedback, as stated by Lu and Law (2012) "students benefit more as assessors than as assesses" (p. 270). These processes also help to clarify the assessment criteria, add greater transparency to the process and open channels for dialogue and improvement.

This point, which is perhaps one of the most novel and significant aspects in competence evaluation, is also undoubtedly the aspect that poses the most technical difficulties when being implemented in a serious game. In our case, although the game was initially designed with a markedly social character, owing to time and budget limitations, this part was unable to be included in the first phase of the game's development. Nonetheless, we believe that this peer interaction and assessment is extremely important, so face-to-face activities to be developed in the classroom have been designed which are integrated with the game and allow to take advantage of the richness of this social aspect. In any case, the design for the second version of the game, planned for 2013, includes small group work. This part requires group members (groups of $2-3$ members) to participate synchronously, and asynchronously (but with time markers) between the different teams ( 4 or 5 per game). In order to do so, different rating and feedback systems have been designed to be used between teams and within a single team (for example, allocating fixed scores to different proposals put forward by other teams, voting within the same team, detailed explanations of the reason for deciding to join to an initiative put forward by others or not, etc.).

All of this has led to a feedback and rating system that takes the competence indicators, games and assessment agents into account, as can be seen in Table 3, where the distribution of scores can be seen in level 1 entrepreneurship competence, which amounts to $65 \%$ of this competence's final rating.

In addition to this global scoring system, a dual pedagogicalludic script has been designed describing each mini game's aims, rules and interaction (Table 4).

\section{DISCUSSION}

Competences assessment is no easy task. Universities face the challenge of introducing the competence-based approach into their study programs, which is complex enough in itself because of the inclusive and systemic nature of the concept of competence. Moreover, the introduction of generic or transversal competences in the curriculums of different university degrees is new to teaching staff, who have to integrate these competences into their subjects' specific set of competences, apply methodologies, often different to those previously used, for competence learning and teaching, deduce assessment criteria and choose the techniques, times and assessment agents to do so. 
Table 4. Sample of the dual pedagogical-ludic script

\begin{tabular}{ll}
\hline \multicolumn{2}{c}{ Pedagogical script } \\
\hline Mini game & Evacuation of the assembly hall \\
\hline Scenario & Assembly hall \\
\hline
\end{tabular}

To develop entrepreneurship competence, in particular at its first I level of mastery: Face everyday reality with initiative, weighing up the risks and opportunities and accepting the consequences.
The university assembly hall must be rid of ghosts in order to retrieve a key needed to access the final scenario.
Players must solve the different everyday life cases. In order to do so, they will need to take decisions by assessing certain aspects relating to the indictors to be assessed.

Certain problems preventing the ghosts from leaving need to be solved in order to empty the assembly hall. Each ghost puts a case to the player and asks them for advice on what to do to solve it. The player must take decisions and the system will give feedback on the appropriateness of their answer, which will build up different scores linked to each of the indicators.

According to the decisions taken by players, they will either solve the problem posed by the ghost (and therefore rid the hall of it) or they will be allowed to analyze why their decisions were inappropriate and will be given another chance to try out a new problem. Success is achieved in the game when the problems posed by all the ghosts in the hall are solved. 1.4 Including social criteria in one's own decision-making.

Feedback plays a key role in the game as it should enable the player to analyze the decisions taken and assess the appropriateness of their answers.

The decisions the person needs to make take all the selected indicators into account proportionally. Each indicator is also exercised in several of the cases in such a way that the player has the chance to exercise the competence and progressively show their progress

feedback on each of the answers chosen by the player. These answers are also rated according to each of the indicators.

On finishing the mini game (or quitting it), the system provides the player with a summary table with the score the player has accumulated in each of the competence achievement indicators.
In principle, serious games are an extremely valuable tool for exercising competences because they enable the creation of reallife or simulated learning scenarios in which the student must solve problems linked to their study or career area, they facilitate active learning, interaction and feedback, and they have a significant element of motivation. However, competence assessment often fails to be made clear in the game. Tasks, activities and mini game performance are assessed, but not exactly the performance level reached by a student in relation to a competence's indicators. This paper has endeavored to progress in this direction by presenting a clearly defined competence assessment model based on levels, indicators and descriptors that has been used as a benchmark for the assessment design of two generic competences: problem solving and entrepreneurship, in a serious game.

The Competence Assessment Model described allows a better definition of the game scenarios and learning activities and provides a reference for a more operational evaluation of students performance through specifications of the competences to be evaluated, as well as a more comprehensive evaluation that the inherent complexity of a competence itself requires.

This paper has analyzed what competence assessment consists of from a theoretical perspective, its contributions in relation to "traditional" assessment, the key elements coming into play (alignment, globality, context, feedback, agents, the grading system and so on) and the difficulties involved. Transferred to a serious game environment, it is true to say that the difficulties increase owing to the system's own limitations when assessing "performance" and integrated knowledge (knowledge, skills, attitudes and values). Even so, establishing indicators grouped into levels of difficulty for each competence (UD Competence Assessment Model) has been of great help in order to define learning and assessment activities and for coherence to exist between them (alignment), and they truly respond to what one wishes to achieve (integrity). In any case, it is thought that effective generic competence assessment should not be confined to the use of a serious game, but rather, that this will constitute one more element, a valuable resource, along with others, which will need to be used by the student within the framework of a more global-learning and teaching strategy.

Important elements of competence assessment have been incorporated into the serious game presented in this paper. However, interesting elements are still to be introduced such as the game's collaborative dimension, self and hetero-assessment as empowering and motivating learning tools and the diversification of assessment strategies, which will be addressed in the second stage of the project. This will also enable us to address level 3 of the Problem Solving and levels 2 and 3 of Entrepreneurship competence, of which collaboration and personal leadership, to name just two, constitute an inherent part.

\section{REFERENCES}

Abt, C. C. (1970). Serious Games. New York: Viking Press.

ADESE (2012). Anuario de la industria del videojuego. Retrieved from http://www.adese.es/index.php?option=com mtree\&task=att downlo ad\&link_id=48\&cf_id=30

Basque Government / Gobierno Vasco (2012). Retratos de juventud 15 . Medios de comunicación. Gobierno Vasco \& Observatorio Vasco de la Juventud.

Biggs, J., \& Tang, C. (2011). Teaching for quality learning at university (4th ed.) Maidenhead: Open university press.

Bologna Declaration (1999). Bologna Declaration. Retrieved from http://www.bologna-bergen2005.no/Docs/00Main doc/990719BOLOGNA DECLARATION.PDF

Boud, D., \& Falchikov, N. (2006). Aligning assessment with long-term learning. Special issue: Learning-oriented assessment: Principles and practice. Assessment \& Evaluation in Higher Education, 31 (4), 399413. doi: $10.1080 / 02602930600679050$

Boud, D., \& Falchikov, N. (2007). Rethinking assessment in higher education: Learning for the longer term. New York: Routledge.

Boyle, E. A., Connolly, T. M., \& Hainey, T. (2011). The role of psychology in understanding the impact of computer games. Entertainment Computing, 2, 69-74. doi: 10.1016/j.entcom.2010.12.002 
Connolly, T. M., Boyle, E. A., MacArthur, E., Hainey, T., \& Boyle, J. M. (2012). A Systematic Literature Review of Empirical Evidence on Computer Games and Serious Games. Computers y Education, 59(2), 661-686. doi: 10.1016/j.compedu.2012.03.004

Crawford, C. (1984). The art of game design. Berkeley: Mcgraw-Hill Osborne Media.

De Freitas, S. (2006). Learning in immersive worlds. London: Joint Information Systems Committee.

De la Orden, A. (2011). El problema de las competencias en la educación general. Bordón: Revista de Pedagogía, 63(1), 47-61

De Miguel, M. (2006). Modalidades de enseñanza centradas en el desarrollo de competencias: Orientaciones para promover el cambio metodológico en el espacio europeo de educación superior. Oviedo: Universidad de Oviedo.

Del Castillo, H., Herrero, D., Monjelat, N., García, A., \& Checa, M. (2011). Identity \& performance: developing innovative educational settings through sport video games. In Proceedings of ICERI 2011 Conference (pp. 236-246). Madrid: International Association of Technology, Education and Development.

Fallows, S., \& Steven, C. (2000). The skills agenda. In S. Fallows and C. Steven. Integrating key skills in higher education; employability, transferable skills and learning for life (pp. 3-14). London: Kogan Page.

Fernández, A. (2010). La evaluación orientada al aprendizaje en un modelo de formación por competencias en la educación universitaria. REDU. Revista de Docencia Universitaria, 8(1), 11-34. Retrieved from

http://redaberta.usc.es/redu/index.php/REDU/article/view/144/120

Ferrell, G. (2012). A view of the assessment and feedback landscape: Baseline analysis of policy and practice from the the JISC assessment \& feedback programme. JISC. Retrieved from http://www.jisc.ac.uk/media/documents/programmes/elearning/Asses sment/JISCAFBaselineReportMay2012.pdf

Gee, J. P. (2003). What Video Games Have to Teach Us About Learning and Literacy. New York: Palgrave Macmillan.

Gee, J. P. (2008). Video Games and Embodiment. Games and Culture, 3 (3-4), 253-263. doi: 10.1177/1555412008317309

Gee, J. P. (2009). Deep learning properties of good digital games how far can they go. In U. Ritterfeld, M. J. Cody \& P. Vorderer (Eds.), Serious Games: Mechanisms and Effects (pp. 65-80). Mahwah, NJ: Taylor \& Francis.

GFK Emer Ad Hoc Research (2010). ¿Cómo se proyecta el videojuego del futuro? Retrieved from ADESE website: http://www.adese.es/pdf/videojuegosimport.pdf

Gonzalez, J., \& Wagenaar, R. (Coords.) (2003). Tuning Educational Structures in Europe (Final Report Phase 1). Bilbao: Universidad de Deusto.

González-Anleo, J. M. et al. (2011). Jóvenes españoles 2010. Madrid: Fundación SM.

Griffin, P., McGaw, B., \& Care, E. (2012). Assessment and teaching of 21st century skills. Dordrecht: Springer. doi: 10.1007/978-94-0072324-5

Gros, B. \& GRUP F9 (2004). Pantallas, juegos y alfabetización digital. Bilbao: Desclée de Brouwer.

Gros, B. (2008). Videojuegos y aprendizaje. Barcelona: Graó.

Guillen-Nieto, V., \& Aleson-Carbonell, M. (2012). Serious games and learning effectiveness: The case of it's a deal! Computers $y$ Education, 58 (1), 435-448. doi: 10.1016/j.compedu.2011.07.015

Haste, H. (2009). What is 'competence' and how should education incorporate new technology's tools to generate 'competent civic agents'. The curriculum journal, 20(3), 207-223. doi: $10.1080 / 09585170903195845$

Holland, D., \& Lave, J. (Eds.) (2001). History in person. Enduring struggles, contentious practice, intimate identities. Santa Fe (USA) \& Oxford: School of American Research Press \& James Currey.

Juul, J. (2005). Video Games and Classic Game Model. Half-Real: Video Games between Real Rules and Fictional Worlds. Cambridge: MIT Press.

Koster, R. (2004). Theory of Fun for Game Design. O'Reilly Media.

Lacasa, P., Méndez, L., \& Martínez, R. (2008). Aprender a contar historias y a reflexionar con videojuegos comerciales. In B. Gros (Ed.). Videojuegos y aprendizaje (pp. 51-72). Barcelona: Graó.

Legault, A. L. (2012). ¿Una enseñanza universitaria basada en competencias? ¿por qué?¿cómo? Revista Electrónica De Desarrollo De Competencias (REDEC), 5(9), 51-83.
Lu, J. \& Law, N. (2012). Online peer assessment: Effects of cognitive and affective feedback. Instructional Science, 40 (2), 257-275. doi: $10.1007 / \mathrm{s} 11251-011-9177-2$

Marcano, B. (2008). Juegos serios y entrenamiento en la sociedad digital. Teoría de la Educación: Educación y Cultura en la Sociedad de la Información, 9(3), 93-107.

Michael, D., \& Chen, S. (2006). Serious Games. Games that educate, train and infoms. Boston: Thompson Course Technology PTR.

O'Neil, H. F., Wainess, R., \& Baker, E. L. (2005). Classification of learning outcomes: Evidence from the computer games literature. The Cirriculum Journal, 16(4), 455-474. doi: $10.1080 / 09585170500384529$

Poblete, M. \& García, A. (2007). Desarrollo de competencias y créditos transferibles: experiencia multidisciplinar en el contexto universitario. Bilbao: Mensajero.

Prensky, M. (2001). Digital Game-Based Learning. London: McGrawHill.

Prensky, M. (2002) The motivation of gameplay: the real twenty-first century learning revolution. On the Horizons, 10(1), 5-11.

Prensky, M. (2005). Engage Me or Enrage Me. What Today's Learners Demand. Educause Review, 40(5), 60-65.

Rodríguez, A., \& Vieira, M. J. (2009). La formación en competencias en la universidad: un estudio empírico sobre su tipología. Revista de Investigación Educativa RIE, 29(1), 27-47.

Salen, K., \& Zimmerman, E. (2004). Rules of Play: Game Design Fundamentals. Cambridge: MIT Press.

Sedeño, A (2010). Videojuegos como dispositivos culturales: las competencias espaciales en educación. Comunicar, 34(17), 183-189.

Squire, K., \& Jenkins, H. (2003). Harnessing the power of games in education. Insight, 3(1), 5-33

Tuning Project (2008). Tuning Educational Structures in Europe. Universities'contribution to the Bologna Process; An Introduction. (4nd ed.). Bilbao: University of Deusto.

Universidad de Deusto (2001). Marco Pedagógico UD. Bilbao: University of Deusto.

Villa, A., \& Poblete, M. (2008). Competence Based Learning. A Proposal for the assessment of generic competences. Bilbao: University of Deusto.

Villa, A., \& Poblete, M. (2011). Evaluación de competencias genéricas: principios, oportunidades y limitaciones. Bordón: Revista de Pedagogía, 63(1), 147-170.

Villa, A., Gonzalez, J., Auzmendi, E., Bezanilla, M. J. \& Laka, J. P. (2003). Learning Outcomes: Competences. In J. Gonzalez \& R. Wagenaar (Eds.). Tuning Educational Structures in Europe. Final Report. Phase 1 (pp. 59-98). Bilbao: University of Deusto.

Wu, W. H., Hsiao, H. C., Wu, P. L., Lin, C. H., \& Huang, S. H. (2011). Investigating the learning-theory foundations of game-based learning: A metaanalysis. Journal of Computer Assisted Learning, 28(3), 265-279. doi: 10.1111/j.1365-2729.2011.00437.x

Wolf, M. J. P., \& Perron, B. (Eds.) (2003). The video game theory reader. New York \& London: Routledge

\section{ACKNOWLEDGMENT}

This project has been carried out thanks to the Provincial Council of Bizkaia, within the framework of BizkaiLab Program aimed to support research at University of Deusto. 